\title{
PERANAN PENGADILAN DALAM PELAKSANAAN PUTUSAN ARBITRASE
}

\author{
Oleh : Joejoen Tjahjani, SH,MH
}

\begin{abstract}
Abstrak
Penyelesaian sengketa bisnis dengan proses adjudikasi dapat diselesaikan para pihak melalui jalur litigasi atau penyelesaian sengketa di muka pengadilan. Tetapi penyelesaian model ini tidak direkomendasikan karena para pihak sangat antagouistis (saling berlawanan satu sama lain) dan juga memakan waktu yang lama. Jadi litigasi atau penyelesaian sengketa di muka pengadilan ini ditempuh semata-mata hanya sebagai jalan yang terakhir atau apabila penyelesaian lewat jalur kekeluargaan atau perdamaian tidak menemukan titik terang atau julan keluar (the last resort atau ultimatum remedium).

Secara teknis, fungsi pengadilan atau tugas mengadili dirumuskan sebagai "memeriksa dan memutus perkara". Memutus perkara atau suatu sengketa tidak selalu sama dengan "menyelesaikan" atau "solution" atau "solving" perkara atau sengketa tersebut. Karena terkadang putusan hakim ada kemungkian memperdalam luka-laka atau mempertajam persengketaan (hakikatnya sengketa itu tidak pernah terselesaikan) bahkan dengan putusan hakim tersebut mengandung potensi atau sengketa perselisihan baru. Berdasarkan hal tersebut di atas, maka perlu sekali ada perubahan orientasi dari "memutuskan perkara" menjadi "menyelesaikan perkara" Peranan pengadilan dalam pelaksanaan putusan arbitrase yang paling utama adalah sebagai eksekutor atau pelaksana putusan arbitrase tersebut. Untuk dapat dilaksanakan eksekusi, putusan arbitrase wajib didaftarkan di Panitera Pengadilan Negeri, karena apabila tidak didaftarkan putusan arbitrase tidak dapat dilakukan eksekusi. Apabila terjadi keterlambatan pendaftaran, putusan arbitrase tetap masih bisa dilaksanakan, namun hal itu tergantung pertimbangan dari Ketua Pengadilan Negeri apakah akan menerima atau menolak eksekusi putusan arbitrase tersebut.
\end{abstract}

\section{Kata Kunci : Peranan Pengadilan, Putusan Arbitrase}

\section{A. Pendahuluan}

\section{Latar Belakang Masalah}

Di dunia modern sekurang ini, perubahan yang sangat cepat begitu terasa dalam segala aspek kehidupan masyarakat. Tidak kecuali dalam hubungan bisnis atau perekonomian, yang pada era super industrialis mengalami perubahan dan pergeseran yang sangat cepat. Dampak perubahan tersebut sangat mempengaruhi bola perekonomian seluruh dunia dan dengan sendirinya membawa bangsa Indonesia ikut kedalamnya.

"Keadaan ini digambarkan John Naisbitt sebagai perubahan yang dihadapi manusia. Dunia yang dihuni manusia telah berubah menjadi global village (perkampungau global) dengan sistem perekonomian single economy." The World moving from trade countries to a single economy one economy. One marketplace"

Perkembangan transaksi bisnis atau perekonomian tadi, di satu sisi memberikan dampak positif dengan meningkatnya penghasilan suatu negara karena setiap bulan hampir ratusan kegiatan bisnis terjadi. Di sisi lain dengan banyaknya jumlah transaksi bisnis dapat pula menimbulkan dampak yang kurang baik seperti terjadinya sengketa antara pelaku bisnis, karena adanya salah satu pihak yang melakukan wanprestasi, perbuatan melawan hukum, beda pendapat maupun beda penafsiran dari kontrak bisnis tersebut. Para pihak dalam hal ini memerlukan pemecahan dan penyelesaian sengketa yang sangat cepat karena akan mengurangi kerugian bagi semua pihak yang terlibat. Untuk penyelesaian sengketa dagang banyak

${ }^{1}$ Margono, Suyud. 2004. ADR (Alternative Dispute Resolutian) dan Arbitrase Proses Pelembagaan dan Aspek Hukum. Lamongan : Ghalia Indonesia, hal 11. 
jalan yang bisa ditempuh mulai dari cara yang sederhana sampai cara yang lebih kompleks.

"Menurut Gary Goodpaster dalam "Tinjauan terhadap penyelesaian sengketa" dalam buku Arbitrase di Indonesia, setiap masyarakat memiliki berbagai macam cara untuk memperoleh kesepakatan dalam proses perkara atau untuk menyelesaikan sengketa dan konflik. Cara yang dipakai pada suatu sengketa tertentu jelas memiliki konsekuensi, baik bagi para pihak yang bersengketa maupun masyarakat dalam arti seluasluasnya. Karena adanya konsekuensi itu, maka sangat diperlukan untuk menyalurkan sengketa-sengketa tertentu kepada suatu mekanisme penyelesaian sengketa yang paling tepat bagi mereka. Ada beberapa hal yang perlu diperhatikan untuk memilih mekanisme yang paling tepat, yaitu bagaimana bentuk persoalan-persoalan para pihak; apa yang diharapkan para pihak untuk dicapai, baik dalam penyelesaian sengketa tertentu ataupun sengketa yang lebih bersifat umum; serta biaya-biaya yang dapat atau sedia ditanggung oleh para pihak. ${ }^{2}$

Penyelesaian sengketa bisnis dengan proses adjudikasi dapat diselesaikan para pihak melalui jalur litigasi atau penyelesaian sengketa di muka pengadilan. Tetapi penyelesaian model ini tidak direkomendasikan karena para pihak sangat antagouistis (saling berlawanan satu sama lain) dan juga memakan waktu yang lama. Jadi litigasi atau penyelesaian sengketa di muka pengadilan ini ditempuh semata-mata hanya sebagai jalan yang terakhir atau apabila penyelesaian lewat jalur kekeluargaan atau perdamaian tidak menemukan titik terang atau julan keluar (the last resort atau ultimatum remedium).

Secara teknis, fungsi pengadilan atau tugas mengadili dirumuskan sebagai

\footnotetext{
${ }^{2}$ Widjaja, Gunawan dan Ahmad Yani. 2000. Seri Hukum Bisnis : Hukum Arbitrase. Lamongan : PT Raja Grafindo Persada hal 3.
}

"memeriksa dan memutus perkara". Memutus perkara atau suatu sengketa tidak selalu sama dengan "menyelesaikan" atau "solution" atau "solving" perkara atau sengketa tersebut. Karena terkadang putusan hakim ada kemungkian memperdalam luka-laka atau mempertajam persengketaan (hakikatnya sengketa itu tidak pernah terselesaikan) bahkan dengan putusan hakim tersebut mengandung potensi atau sengketa perselisihan baru. Berdasarkan hal tersebut di atas, maka perlu sekali ada perubahan orientasi dari "memutuskan perkara" menjadi "menyelesaikan perkara"

Model yang tapat untuk penyelesaian sengketa dari perubahan orientasi "memutuskan perkara" menjadi "menyelesaikan perkara" adalah dengan menempuh jalan Alternative Dispute Resolution (ADR) atau Alternatif Penyelesaian Sengketa. Konsep ADR pertama kali muncul di Amerika Serikat sebagai jawaban atas reaksi masyarakat Amerika Serikat sendiri terhadap sistem peradilan mereka. Ketidakpuasan yang dimaksud bersumber pada persoalan waktu yang digunakan sangat lama dengan biaya sangat mahal serta diragukan kemampuannya dalam menyelesaikan secara memuaskan kasuskasus yang rumit. Meskipun masyarakat Amerika Serikat terkenal sebagai masyarakat modem dengan didominasi oleh cara ligitasi dengan selalu meneriakkan kata "see you in court", walaupun masalah yang dihadapi atau masalah yang disengketakan adalah masalah kecil atau sepele

Bagi dunia peradilan kehadiran arbitrase atau cara-cara lain penyelesaian sengketa di luar proses pengadilan sangat penting. Berkembang praktek arbitrase atau cara-cara lain di luar pengadilan (tentunya di luar "debt collectors") akan mengurangi jumlah perkara di pengadilan, yang pada gilirannya sudah barang tentu akan mengurangi beban perkara yang masuk ke pengadilan dan pada akhirnya akan berimbas pula pada efektifitas kerja. Majelis hakim dalam memeriksa mempertimbangkan dan memutus perkara, karena dengan sedikit perkara majelis hakim akan lebih konsentrasi dalam menghadapi perkara di pengadilan.

Lembaga arbitrase masib memiliki ketergantungan pada pengadilan, misalnya dalam hal pelaksanaan putusan arbitrase. Ada 
keharusan untuk mendaftarkan putusan arbitrase di pengadilan negeri. Hal ini menunjukkan bahwa lembaga arbitrase tidak mempunyai upaya pemaksa terhadap para pihak untuk mentaati putusannya. Peranan pengadilan dalam penyelenggaraan arbitrase berdasar UU No. 30 Tahun 1999 tentang Arbitrase dan Alternatif Penyelesaian Sengketa antara lain mengenai penunjukkan arbiter atau majelis arbiter dalam hal para pihak tidak ada kesepakatan Pasal 14 ayat (3) dan dalam hal pelaksanaan putusan arbitrase nasional maupun internasional yang harus dilakukan melalui mekanisme sistem peradilan yaitu pendaftaran putusan tersebut dengan menyerahkan salinan oteritik putusan. Bagi arbitrase internasional mengambil tempat di Pengadilan Negeri Lamongan.

Putusan arbitrase yang dijatuhkan arbiter pada realisasinya merupakan kewajiban dari pihak yang kalah dalam sengketa untuk memenuhi prestasi, dan sebaliknya merupakan hak bagi pihak yang menang. Hukum eksekusi atas putasan arbitrase tersebut baru bisa digunakan apabila pihak yang kalah tidak menjalankan kewajiban sebagaimana mestinya. Pelaksanaan eksekusi putusan arbitrase tidak semudah yang dibayangkan, banyak prosedur yang harus dilaksanakan hingga putusan tersebut benar-benar terlaksana. Penjelasan Pasal 61 UU No. 30 Tahun 1999 tentang Arbitrase dan Alternatif Penyelesaian Sengketa bahwa apabila pelaksanaan putusan tersebut tidak dilakukan secara sukarela maka eksekusi dilaksanakan berdasarkan perintah Ketua Pengadilan Negeri.

\section{Peumusan Masalah}

Berdasarkan latar belakang masalah yang dipaparkan di atas, maka dapat dirumuskan beberapa rumusan masalah sebagai berikut :

1. Bagaimana peranan pengadilan dalam pelaksanaan putusan arbitrase ?

2. Apakah kendala-kendala yang dihadapi pengadilan dalam pelaksanaan putusan arbitrase ?

\section{Tujuan Penelitian}

Berdasarkan permasalahan di atas, maka tujuan dari penelitian ini adalah :
1. Untuk mengetahui bagaimana peranan pengadilan dalam pelaksanaan putusan arbitrase.

2. Untuk mengetahui apakah kendalakendala yang dihadapi pengadilan dalam pelaksanaan putusan arbitrase.

A. Kajian Teori Tinjauan Umum Tentang Arbitrase

1. Pengertian Arbitrase

Di Indonesia minat untuk menyelesaikan sengketa melalui arbitrase mulai meningkat sejak diundangkannya Undang-undang Nomor 30 Tahun 1999 Tentang Arbitrase dan Alternatif Penyelesaian Sengketa (UU Arbitrase). Perkembangan ini sejalan dengan arah globalisasi, di mana penyelesaian sengketa di luar pengadilan telah menjadi pilihan pelaku bisnis untuk menyelesaikan sengketa bisnis mereka. Selain karakteristik cepat, efisien dan tuntas, arbitrase menganut prinsip winwin solution, dan tidak bertele-tele karena tidak ada lembaga banding dan kasasi. Biaya arbitrase juga lebih terukur, karena prosesnya lebih cepat. Keunggulan lain arbitrase adalah putusannya yang serta merta (final) dan mengikat (binding), selain sifatnya yang rahasia (ccnfidential) di mana proses persidangan dan putusan arbitrase tidak dipublikasikan. Berdasarkan atas timbal balik putusan-putusan arbitrase asing yang melibatkan perusahaan asing dapat dilaksanakan di Indonesia, demikian putusan arbitrase Indonesia yang melibatkan perusahaan asing akan dapat dilaksanakan diluar negeri.

Istilah arbitrase menurut bahasa Latin dikenal dengan kata arbitrare, kemudian diikuti oleh istilah dari beberapa Negara diantaranya arbitrase (Belanda/Perancis), arbitration (lnggris) dan shiedpruch (Jerman), yang berarti kekuasaan untuk menyelesaikan sesuatu menurut kebijaksanaan atau perdamaian melalui arbiter atau wasit.

Sedangkan menurut Pasal I angka (1) UU No. 30 Tahun 1999 tentang Arbitrase dan Alternatif Penyelesaian Sengketa memberikan pengertian tersendiri mengenai arbitrase, 
yaitu cara penyelesaian suatu sengketa perdata di luar peradilan umum yang didasarkan pada perjanjian arbitrase yang dibuat secara tertulis oleh para pihak yang bersengketa.

Definisi Pasal I angka (1) UU

No. 30 Tahun 1999 tentang Arbitrase dan Alternatif Penyelesaian Sengketa di atas, dapat ditarik beberapa karakteristik yuridis dari arbitrase. Karakteristik yuridis tersebut adalah sebagai berikut.:

1. Adanya kontroversi di antara para pihak.

2. Kontroversi tersebut diajukan kepada arbiter.

3. Arbiter diajukan oleh para pihak atau ditunjuk oleh tertentu.

4. Arbiter adalah pihak diluar badan peradilan umum

5. Dasar pengajuan sengketa ke arbitrase adalah perjanjian

6. Arbiter melakukan pemeriksaan perkara

7. Setelah memeriksa perkara, arbiter akan memberikan putusan arbitrase tersebut dan mengikat para pihak.

\section{Objek Arbitrase}

Sengketa yang terjadi diantara para pihak tidak semuanya bisa diselesaikan lewat jalur arbitrase, hanya sengketa tertentu saja yang bisa dijadikan sebagai objek perjanjian arbitrase. Pasal 5 ayat (1) UU NO. 30 Tahun 1999 tentang Arbitrase dan Alternatif Penyelesaian Sengketa menyatakan bahwa "Sengketa yang dapat diselesaikan melalui arbitrase hanya sengketa di bidang perdagangan dan mengenai hak yang menurut hukum dan perundang-undangan dikuasai sepenuhnya oleh pihak yang bersengketa". Adapun ruang lingkup kegiatan dalam bidang perdagangan diatur dalam penjelasan Pasal 66 UU No. 30 tahun 1999 tentang Arbitrase dan Alternatif Penyelesaian Sengketa antara lain : Perniagaan, perbankan, keuangan, penanaman modal, industri dan hak milik intelektual.

UU No. 30 tahun 1999 tentang Arbitrase dan Alternatif Penyelesaian Sengketa juga mengatur mengenai sengketa yang tidak dapat dijadikan objek arbitrase. Sebagaimana yang tercantum dalam Pasal 5 ayat (2) UU No. 30 Tahun 1999 tentang Arbitrase dan Alternatif Penyelesaian Sengketa menjelaskan bahwa "Sengketa yang tidak dapat diselesaikan melalui arbitrase adalah sengketa yang menurut peraturan perundang-undangan tidak dapat diadakan perdamaian", sebagaimana diatur dalam KUH Perdata Buku III Bab ke 18 Pasal 1851 s/d 1854 seperti perkawinan (perceraian) dan kepailitan.

\section{Keunggulan dan Kelemahan Arbitrase} Penyelesaian sengketa dengan arbitrase memiliki keunggulan dibandingkan dengan pranata peradilan umum yang dapat disimpulkan melalui penjelasan umum dalam UU No. 30 Tahun 1999 tentang Arbitrase dan Alternatif Penyelesaian Sengketa. Beberapa keunggulan dari arbitrase adalah :

a. Kerahasiaan sengketa para pihak terjamin.

b. Keterlambatan yang diakibatkan karena hal prosedural dan administratif dapat dihindari.

c. Para pihak dapat memilih arbiter yang berpengalaman, memiliki latar belakang yang cukup mengenai masalah yang disengketakan, serta jujur dan adil.

d. Para pihak dapat menentukan pilihan hukum untuk penyelesaian masalahnya, serta para pihak dapat memilih tempat penyelenggaraan arbitrase.

e. Putusan arbitrase merupakan putusan yang mengikat para pihak melalui prosedur sederhana ataupun dapat langsung dilaksanakan.

Berdasarkan pendapat Munir Fuady kelebihan arbitrase dibanding dengan lembaga pengadilan antara lain. ${ }^{3}$

a. Prosedur tidak berbelit dan keputusan dapat dicapai dalam waktu relatif singkat.

b. Biaya lebih murah.

${ }^{3}$ Fuady, 2000. Arbitrase Nasional (Alternatif Penyelesaian Sengketa Bisnis). Bandung : PT Citra Aditya Bakti, hal 94 
c. Dapat dihindari expose dari keputusan di depan umum.

d. Hukum terhadap prosedur dan pembuktian lebih relaks.

e. Para pihak dapat memilih hukum mana yang akan diberlakukan oleh arbitrase.

f. Para pihak dapat memilih sendiri para arbiter.

g. Dapat dipilih para arbiter dari kalangan ahli dalam bidangnya.

h. Keputusan dapat lebih terkait dengan situasi dan kondisi.

i. Keputusannya umumnya final dan binding (tanpa harus naik banding atau kasasi).

j. Keputusan arbitrase umumnya dapat diberlakukan dan dieksekusi oleh pengadilan dengan sedikit atau tanpa review sama sekali.

k. Proses atau prosedur arbitrase lebih mudah dimengerti oleh masyarakat luas.

1. Menutup kemungkinan untuk dilakukan "forum shopping".

Berdasarkan pendapat Munir Fuady kekurangan arbitrase dibanding dengan lembaga pengadilan antara lain. ${ }^{4}$

a. Hanya baik dan tersedia dengan baik terhadap perusahaanperusahaan bonafide.

b. Due process kurang terpenuhi.

c. Kurangnya unsur finality.

d. Kurangnya power untuk menggiring para pihak ke settlement.

e. Kurangnya power untuk menghadirkan barang bukti, saksi dan lain-lain.

f. Kurangnya power untuk hal law enforcement dan eksekusi keputusan.

g. Dapat menyembunyikan dispute dari "public scrutiny".

h. Tidak dapat menghasilkan solusi yang bersifat prevertif.

4 Fuady, Munir. 2000. Arbitrase Nasional (Alternatif Penyelesaian Sengketa Bisnis). Bandung : PT Citra Aditya Bakti, hal: 95 i. Kemungkinan timbulnya keputusan yang saling bertentangan satu sama lain karena tidak ada sistem "precedent" terhadap keputusan sebelumnya dan juga karena unsur fleksibilitas dari arbiter. Karena itu, keputusan arbitrasa tidak predektif.

j. Kualitas keputusannya sangat bergantung pada kualitas para arbiter itu sendiri, tidak ada norma yang cukup untuk menjaga standar mutu keputusan arbitrase. Oleh karena itu sering dikatakan "an arbitration is as good as arbritators".

k. Bcrakibat kurangnya upaya untuk mengubah sistem pengadilan konvensional yang ada.

1. Berakibat semakin tinggi rasa permusuhan kepada pengadilan.

\section{Bentuk-bentuk Arbitrase}

Klausula arbitrase harus memuat pernyataan apakah arbitrase akan dilakukan secara lembaga institusional atau ad hoc. Pada dasarnya bentuk arbitrase ada dua jenis, yaitu arbitrase ad hoc (volunteer) dan arbitrase institusional (permanent). Arbitrase ad hoc adalah arbitrase yang dibentuk khusus untuk menyelesaikan atau memutuskan perselisihan tertentu, atau dengan kata lain arbitrase ad hoc bersifat insidential. Sedangkan arbitrase institusional (institusional arbitration) merupakan lembaga atau badan arbitrase yang bersifat permanen sehingga disebut "permanent arbitral body".

Perbedaan antara kedua bentuk arbitrase ini adalah: Arbitrase ad hoc adalah arbitrase yang tidak terkoordinasi oleh suatu lembaga. Sedangkan arbitrase institusional adalah suatu arbitrase yang dikoordinasikan oleh suatu lembaga.

a. Arbitrase ad hoc dibentuk secara khusus atau bersifat insidentil untuk memeriksa dan memutus perselisihan sengketa tertentu dalam ,jangka waktu tertentu pula. Setelah memutus 
sengketa, berakhir pula arbitrase ad hoc ini. Arbitrase institusional adalah arbitrase yang melembaga yang didirikan dan melekat pada suatu badan (body) atau lembaga (institution) tertentu. Sifatnya permaren dan sengaja dibentuk guna menyelesaikan sengketa yang terjadi sebagai akibat pelaksanaan perjanjian. Setelah selesai memutus sengketa, arbitrase institusional tidak berakhir.

b. Arbitrase ad hoc tidak terkait dengan salah satu badan atau lembaga, sehingga tidak memiliki aturan tata cara tersendiri, banyaknya pengangkatan arbiternya maupun mengenai tata cara pemeriksaan sengketa. Pada arbiternya ditentukan dan dipilih sendiri berdasarkan kesepakatan para pihak. Sedangkan arbitrase institusional memiliki prosedur dan tata cara pemeriksaan sengketa tersendiri. Arbiternya ditentukan dan diangkat oleh lembaga arbitrasi institusional sendiri.

c. Pembentukan arbitrase ad hoc dilakukan setelah sengketa terjadi. Para pihak yang bersengketa yang memilih dan menentukan arbiternya atau bisa pula meminta bantuan pengadilan untuk mengangkat arbiternya, yang bertugas memeriksa dan memutuskan sengketa yang bersangkutan. Sedangkan arbitrase institusional pada umumnya dipilih oleh para pihak sebelum sengketa terjadi, dan dituangkan perjanjian arbitrase.

\section{Tinjauan Tentang Alternatif Penyelesaian Sengketa \\ 1. Pengertian Alfernatif Penyelesaian Sengketa}

Alternatif penyelesaian sengketa atau dalam istilah asingnya Alternative Dispute Resolution (ADR) sebenarnya sudah dikenal oleh masyarakat Indonesia sejak lama. Hal ini bisa dilihat dari adanya penyelesaian sengketa secara konsensus yang dilakukan oleh masyarakat adat yang ada diseluruh penjuru Indonesia, yang pada intinya mengupayakan jalur musyawarah mufakat, kekeluargaan, perdamaian dan sebagainya yang menggunakan istilah yang hampir sama. $\begin{array}{ll} & \text { Sejarah perkembangan ADR di } \\ \text { negara tempat pertama kali } \\ \text { dikembangkan (Amerika Serikat), }\end{array}$ pengembangan ADR dilatarbelakangi oleh kebutuhan sebagai berikut (Margono, 2004 : 35) :

5. Mengurangi kemacetan di pengadilan. Banyaknya kasus yang diajukan ke pengadilan menyebabkan proses pengadilan seringkali berkepanjangan sehingga memakan biaya yang tinggi dan sering memberikan hasil yang kurang memuaskan.

6. Meningkatkan ketertiban masyarakat dalam proses penyelesaian sengketa.

7. Memperlancar serta memperluas akses ke pengadilan.

8. Memberikan kesempatan bagi tercapainya penyelesaian sengketa yang menhasilkan keputusan yang dapat diterima oleh semua pihak dan memuaskan.

Sehubungan dengan berjalannya waktu ADR berkembang dan memiliki padanannya dalam bahasa Indonesia yang diperkenalkan dalam berbagai istilah oleh beberapa pihak yang diantaranya adalah Pilihan Penyelesaian Sengketa (PPS), Mekanisme Alternatif Penyelesaian Sengketa (MAPS), Pilihan Penyelesaian Sengketa di luar pengadilan dan Mekanisme Penyelesaian Sengketa secara kooperatif.

$$
\text { Philip D Bostwick }
$$

mengemukakan definisi yang lebih sempit dan akademis mengenai ADR dengan menyatakan bahwa ADR adalah serangkaiaan praktik dan teknik-teknik hukum yang ditujukan untuk:: 
a. Memungkinkan sengketa-sengketa hukum diselesaikan di luar pengadilan untuk keuntungan atau kebaikan para pihak yang bersengketa.

b. Mengurangi biaya atau keterlambatan kalau sengketa tersebut diselesaikan melalui litigasi konvensional.

c. Mencegah agar sengketa-sengketa hukum tidak dibawa ke pengadilan.

Dalam Pasal I angka (10) UU No. 30 Tahun 1999 tentang Arbitrase dan Alternatif Penyelesaian Sengketa memberikan penjelasan mengenai makna dari Alternatif Penyelesaian Sengketa adalah lembaga penyelesaian sengketa atau beda pendapat melalui prosedur yang disepakati para pihak, yakni penyelesaian di luar pengadilan dengan cara konsultasi, negosiasi, mediasi, konsiliasi, atau penilaian ahli. Pasal 6 ayat (1) UU No. 30 Tahun 1999 tentang Arbitrase dan Alternatif Penyelesaian Sengketa juga memberi penjelasan mengenai ADR bahwa sengketa atau beda pendapat dapat diselesaikan oleh para pihak melalui Alternatif Penyelesaian Sengketa yang didasarkan pada itikad haik dengan mengesampingkan penyelesaian secara litigasi di Pengadilan Negeri.

Menurut Joni Emerzon pengertian dari alternatif penyelesaian sengketa adalah suatu poses penyelesaian sengketa non litigasi dimana para pihak yang bersengketa dapat membantu atau dilibatkan dalam penyelesaian persengketaan tersebut atau melibatkan pihak ketiga yang bersifat netral.

Pada hakikatnya ADR biasa juga diartikan sebagai alternative to litigation atau alternative to adjudication, yang sering menimbulkan implikasi yang tidak sama. Apabila diartikan sebagai alternative to litigation berarti semua mekanisme penyelesaian sengketa di luar pengadilan, sehingga dalam hal ini, arbitrase termasuk bagian dari ADR. Scdangkan apabila diartikan sebagai alternative to adjudication berarti mekanisme penyelesaian sengketa yang bersifat kousensus atau kooperatif, tidak melalui prosedur pengajuan gugatan kepada pihak ke tiga yang berwenang mengambil keputusan. Termasuk bagian dari ADR adalah konsultasi, negosiasi, konsiliasi dan pendapat ahli, sedangkan arbitrase bukan termasuk ADR.

Beberapa penjelasan mengenai alternatif penyelesaian sengketa yang dipaparkan diatas, maka dapat diperoleh kesimpulan bahwa pada intinya alternatif penyelesaian sengketa merupakan suatu cara menyelesaikan sengketa tanpa melalui pengadilan umum dengan mengedepankan musyawarah yang didasarkan pada itikad baik antara para pihak yang bersengketa dan dengan pihak ketiga sebagai penengah untuk mencari solusi dari permasalahan sehingga tercapai kesepakatan.

\section{Sumber Hukum Alternatif Penyelesaian Sengketa}

Seperti halnya hukum pada umumnya, ADR juga mengenal sumber hukum, untuk sekarang ini terdapat dalam UU No. 30 Tahun 1999 tentang Arbitrase dan Alternatif Penyelesaian Sengketa yang kemudian dipertegas dalam UU No. 4 Tahun 2004 tentang Kekuasaan kehakiman. Selain itu ADR juga memiliki sumber hukum lain yang lebih menekankan aspek kekeluargaan dan perdamaian telah ada dan dapat ditemukan dalam berbagai aturan hukum yang terdahulu. Sumber hukum ADR pada intinya juga merupakan sumber hukum arbitrase. Sebagai ketentuan terbaru yang mengatur lembaga arbitrase, maka pemerintah mengeluarkan UU No. 30 Tahun 1999 tentang Arbitrase dan Alternatif Penyelesaian Sengketa atau yang biasa disebut UU Arbitrase, pada tanggal 12 Agustus 1999 yang dimaksudkan untuk menggantikan peraturan mengenai lembaga arbitrase yang tidak sesuai lagi dengan perkembangan zaman dan kemajuan perdagangan internasional. Oleh karena itu ketentuan mengenai arbitrase sebagaimana dimaksud dalam Pasal 615 s/d 651 RV, Pasal 377 HIR, dan Pasal 705 RBG, dinyatakan tidak berlaku lagi. Dengan demikian ketentuan hukum acara dari lembaga arbitrase saat ini telah mempergunakan ketentuan yang terdapat dalam UU No. 30 Tahun 1999 tentang 
Arbitrase dan Alternatif Penyelesaian Sengketa.

\section{Macam-Macam Alternatif Penyelesaian Sengketa}

Pasal 1 angka (10) UU No. 30

Tahun 1999 tentang Arbitrase dan Alternatif Penyelesaian Sengketa yang menyatakan bahwa alternatif penyelesaian sengketa dapat dilakukan dengan cara konsultasi, negosiasi atau perdamaian, mediasi, konsilidasi dan atau penilaian ahli. Untuk memberikan gambaran terhadap macam-macam dari ADR, maka berikut ini akan diuraikan secara singkat masing-masing bentuk ADR yang telah disebutkan oleh UU No. 30 Tahun 1999 tentang Arbitrase dan Alternatif Penyelesaian Sengketa maupun berbagai varian ADR lainnya

a. Konsultasi

Merupakan suatu tindakan yang bersifat personal antara suatu pihak tertentu yang disebut klien dengan pihak lain yang disebut konsultan, yang memberikan pendapatnya pada klien tersebut untuk memenuhi kebutuha atau keperluannya.

b. Negosiasi atau perdamaian Fisher dan Ulry mengemukakan bahwa negosiasi adalah poses komunikasi dua arah yang dirancang untuk mencapai lesepakatan pada saat kedua belah pihak memiliki berbagai kepentingan yang sama maupun berbeda, tanpa melibatkan pihak ketiga sebagai penengah.

c. Mediasi atau penengahan Mediasi merupakan mekanisme penyelesaian sengketa dengan bantuan pihak ketiga (modiator) yang tidak memihak (impartial) yang turut aktif memberikan bimbingan atau arah guna mencapai penyelesaian. Namun ia tidak berfungsi sebagai hakim yang berwenang mengambil keputusan. Inisiatif penyelesaian tetap berada pada tangan para pihak yang bersengketa. Dengan demikian hasil penyelesaian bersifat kompromi.

d. Konsiliasi atau permufakatan
Konsiliasi

penyelesaian sengketa dengan intervensi pihak ketiga (konsiliator). Konsiliator lebih bersifat aktif, dengan mengambil inisiatif menyusun dan memutuskan langkah-langkah penyelesaian, yang selanjutnya diajukan dan ditawarkan kepada para pihak yang bersengketa. Jika pihak yang bersengketa tidak mampu merumuskan suatu kesepakatan, maka pihak ketiga mengajukan usulan jalan keluar dari sengketa. Meskipun demikian konsiliator tidak berwenang membuat putusan, tetapi hanya berwenang membuat rekomendasi yang pelaksanaannya sangat tergantung dari itikad baik para pihak yang bersengketa sendiri.

e. Penilaian ahli atau pendapat hukum Pendapat hukum yang diberikan lembaga arbitrase bersifat mengikat (binding) oleh karena itu, pendapat yang diberikan tersebut akan menjadi bagian yang tidak terpisahkan dari perjanjian pokok (yang dimintakan pendapatnya pada lembaga arbitrase tersebut). Setiap pendapat yang berlawanan terhadap pendapat hukum yang diberikan tersebut berarti pelanggaran terhadap perjanjian (breach of contract wanprestasi). Oleh karena itu, tidak dapat dilakukan perlawanan dalam bentuk upaya hukum apapun.

f. Good office atau jasa baik

Good office merupakan penyelesaian sengketa dengan bantuan pihak ketiga yang memberikan jasa baik berupa penyediaan tempat atau fasilitasfasaitas untuk digunakan oleh para pihak yang bersengketa untuk melakukan musyawarah atau perundingan guna mencapai penyelesaian. Inisiatif penyelesaian tetap berada ditangan para pihak, sedangkan pihak ketiga bersifat pasif.

4. Keunggulan dan Kelemahan Alternatif Penyelesaian Sengketa Menurut Chistoper W. Noor, ADR dianggap lebih cocok dari pada 
melalui jalur pengadilan dengan alasanalasan sebagai berikut::

a. Sifat kesukarelaan dalam proses

b. Prosedur cepat

c. Keputusan nonjudisial

d. Prosedur rahasia

e. Fleksibilitas yang besar dalam merancang syarat-syarat penyelesaian masalah

f. Hemat waktu dan biaya

g. Perlindungan dan pemeliharaan hubungan kerja

h. Kemungkinan untuk melaksanakan kesepakatan tinggi, karena didasarkan win-win solution.

Meskipun ADR memiliki beberapa keunggulan, tetapi ADR sebenarnya merupakan mekanisme yang rentan terutama untuk kondisi di Indonesia, karena ADR juga mempunyai kelemahan-kelemahan, di antaranya:

a. ADR belum dikenal secara luas, baik oleh masyarakat awam, maupun masyarakat bisnis bahkan oleh masyarakat akademis. Sebagai contoh masyarakat masih banyak yang belum mengetahui keberadaan dan kiprah dari lembaga-lembaga seperti BANI, BAPMUI, dan P3BI.

b. Masyarakat belum menaruh kepercayaan yang memadai, sehingga enggan memasukkan perkaranya kepada lembaga-lembaga ADR. Hal ini dapat dilihat dari sedikitnya perkara yang diajukan dan diselesaikan melalui lembagalembaga ADR yang ada.

c. Lembaga ADR tidak mempunyai kewenangan melakukan eksekusi putusannya. Meskipun keputusan arbitrase bersifat mengikat, tetapi untuk melaksanakannya harus melalui "fiat eksekusi" pengadilan. Jadi wibawa arbitrase kalah dengan wibawa pengadilan.

d. Kurangnya kepatuhan para pihak terhadap hasil-hasil penyelesaian yang dicapai dalam ADR, sehingga mereka seringkali mengingkari dengan berbagai cara, baik dengan teknik mengulur-ulur waktu perlawanan, gugatan pembatalan dan sebagainya. e. Kurangnya kesediaan para pihak yang bersengketa untuk melepaskan sebagian hak-haknya. Budaya litigasi yang sudah tertanam, membuat para pihak berfikir winlose solution dan bukan win-win solution sebagaimana yang dikehendaki oleh ADR.

f. Kurangnya para pihak memegang etika bisnis. Sebagai suatu mekanisme extra Judicial, ADR hanya dapat bertumpu di atas etika bisnis, seperti kejujuran dan kewajaran.

\section{Metode Penelitian}

1. Tipe Penelitian

Tipe penelitian hukum yang dilakukan adalah yuridis normatif (hukum normatif). Metode penelitian hukum normatif adalah suatu prosedur penelitian ilmiah untuk menemukan kebenaran berdasarkan logika keilmuan hukum dari sisi normatifnya. ${ }^{5}$

Oleh karena itu penelitian hukum ini difokuskan untuk mengkaji penelitian hukum tentang kaidah-kaidah atau norma-norma dalam hukum positif, yakni norma hukum yang terkait dengan penyelesaian sengketa melalui arbitrse.

\section{Pendekatan Masalah}

Oleh karena tipe penelitian yang digunakan adalah tipe penelitian yuridis normatif, maka pendekatan yang digunakan adalah pendekatan perundangundangan (statute approach). Pendekatan tersebut melakukan pengkajian peraturan perundang-undangan yang berhubungan dengan pokok permasalahan. Selain itu juga digunakan pendekatan kasus (cass approach). Pendekatan kasus ini digunakan dalam rangka untuk melihat kasus kasus yang penyelesaiaannya melalui arbitrase.

5 Johnny Ibrahim, Teori \& Metode

Penelitian Hukum Normatif, Banyumedia

Publishing, Malang 2006, h..57 


\section{Bahan Hukum}

Bahan hukum yang dipergunakan dalam penelitian ini adalah sebagai berikut :

1) Bahan hukum primer: bahan hukum primer merupakan bahan hukum yang bersifat autoritatif artinya mempunyai otoritas bahan hukum terdiri dari perundang-undangan, catatan resmi, atau risalah dalam pembuatan perundangundangan dan putusan hakim. Adapun bahan hukum primer antara lain: UndangUndang dasar 1945. Kitab Undangundang Hukum Perdata, UU No. 30 Tahun 1999 tentang Arbitrase dan Alternatif Penyelesaian Sengketa., UU No. 4 Tahun 2004 tentang Pokok-pokok Kekuasaan Kehakiman, Peraturan Prosedur Arbitrase Badan Arbitrase Nasional Indonesia, Kepres No. 34 Tahun 1981 tentang Pengakuan Konvensi New York 1958.

b. Bahan sekunder, yaitu bahan yang diperoleh dari buku teks, jurnal-jurnal, pendapat para sarjana dan kasus-kasus hukum. ${ }^{6}$

4. Prosedur Pengumpulan Bahanbahan

Baik bahan primer maupun bahan sekunder dikumpulkan berdasar-kan topik permasalahan yang telah dirumuskan dan diklasifikasi menurut sumber dan hirarkinya untuk dikaji secara komprehensif.

\section{Pengolahan dan Analisis Bahan} Hukum

Adapun bahan yang diperoleh dalam penelitian studi kepustakaan, aturan perundang-

${ }^{6}$ Peter Mahmud Marzuki. Penelitian Hukum. Universitas Air Langga. Surabaya. h. 15. undangan, yang penulis uraikan dan dihubungkan sedemikian rupa, sehingga disajikan dalam penulisan yang lebih sistematis guna menjawab perumusan masalah yang dirumuskan. Cara pengolahan data dilakukan secara deduktif yakni menarik kesimpulan dari suatu permasalahan yang bersifat umum terhadap permasalahan kongkrit yang dihadapi.

\section{Hasil Penelitian Dan Pembahasan Peranan Pengadilan dalam Pelaksanaan Putusan Arbitrase}

Penyelesaian sengketa arbitrase dalam setiap akhir prosesnya, seorang arbiter atau mejelis arbiter harus menjatuhkan putusan arbitrase sebagai inti dari pemecahan masalah dengan memberikan kewajiban pada pihak yang dikalahkan untuk memenuhi suatu prestas yang kemudian merupakan trek bagi pihak yang menang. Suatu putusan arbitrase tadi harus dilaksanakan oleh pihak yang kalah secara sukarela untuk memenuhi prestasinya. Apabila pihak yang kalah tidak melaksanakan secara sukarela, pihak yang menang dapat menggunakan hukum eksekusi yang pelaksanaannya dilakukan oleh pengadilan.

Pengadilan dalam hukum eksekusi merupakan pelaksana untuk melakukan eksekusi putusan arbitrase secara paksa apabila pihak yang kalah tidak melakukan prestasinya secara sukarela. Untuk pelaksanaan putusan arbitrase, pengadilan berpedoman kepada UU No. 30 Tahun 1999 tentang Arbitrase dan Alternatif Penyelesaian Sengketa, Konvensi New York 1958 tentang Pengakuan dan Pelaksanaan Arbitrase Internasional atau asing, serta PERMA No. 1 Tahun 1990 tentang Tata Cara Pelaksanaan Putusan Arbitrase Asing.

Pelaksanaan putusan arbitrase sebelum mendapatkan bantuan peran dari pengadilan harus melakukan deponir dahulu untuk pendaftaran di Panitera Pengadilan Negeri. Pendaftaran dan pencatatan putusan arbitrase kepada Panitera Pengadilan Negeri merupakan tindakan yang wajib dilakukan bagi pihak yang berkepentingan atas pelaksanaan putusan arbitrase, apabila ingin melakukan pelaksanaan putusan secara paksa karena putusan tersebut tidak dilaksanakan secara sukarela. Pendaftaran tersebut 
merupakan dasar bagi pelaksanaan putusan arbitrase oleh pengadilan atas permintaan pihak yang berkepentingan.

Apabila setelah melakukan pendaftaran deponir dan salah satu pihak tidak ada yang ingin melakukan pembatalan, kemudian pihak yang kalah tidak melakukan kewajibannya secara sukarela, maka pihak yang berkepentingan dapat melakukan permohonan eksekusi putusan arbitrase itu sendiri, dengan pengadilan selaku pihak pelaksananya. Adapun peranan pengadilan dalam pelaksanaan eksekusi tersebut dirumuskan sebagai berikut :

1. Pemberian exequatur

Pemberian exequatur terhadap putusan arbitrase dilakukan dengan cara membuat surat permohonan exequatur kepada Ketua Pengadilan Negeri, sebagai permintaan untuk melakukan eksekusi terhadap putusan arbitrase. Permintaan untuk permohonan exequatur dilakukan sendiri oleh para pihak yang berkepentingan kepada Pengadilan Negeri, karena arbiter tidak terlibat lagi setelah pendaftaran deponir. Pada hakikatnya untuk bisa dilakukan exequatur dari pergadilan diperlukan pendaftaran deponir terlebili dahulu, apabila pendaftaran deponirnya melebihi batas waktu yang telah ditentukan, akan menjadi pertimbangan Ketua Pengadilan Negeri untuk menerima atau menolak permohonan exequatur tersebut. Apabila putusan tidak dapat dieksekusi maka pemberian exequatur ditolak dengan keluarnya surat penetapan dilengkapi dengan alasan pertimbangannya. Namun jika putusan tersebut dapat dieksekusi maka Ketua Pengadilan dapat memberikan exequatur dan selanjutnya akan mengeluarkan penetapan perintah eksekusi.

2. Penetapan Perintah Eksekusi

Penetapan perintah eksekusi dikeluarkan oleh Ketua Pengadilan Negeri setelah memberikan exequatur terhadap putusan. Jadi Sebelum menolak atau menerima exequatur yang kemudian mengeluarkan penetapan perintah eksekusi Ketua Pengadilan Negeri harus mempelajari dan meneliti terlebih dahulu putusan arbitrase apakah bisa dilakukan eksekusi atau tidak sesuai dengan ketentuan Pasal 62 ayat (2) UU No. 30 Tahun 1999 tentang Arbitrase dan Alternatif Penyelesaian Sengketa. Ketua Pengadilan Negeri mengeluarkan surat penetapan perintah pengadilan setelah mempertimbangkan apakah putusan arbitrase tersebut dapat dieksekusi dengan tidak ditemukan cacat seperti putusan dijatuhkan majelis arbitrase yang tidak berwenang, melebihi batas kewenangan arbiter, bertentangan dengan kesusilaan.

3. Melakukan teguran atau Aanmaning Penerapan perintah eksekusi telah dikeluarkan oleh Ketua Pengadilan Negeri, maka peran pengadilan berikutnya adalah melakukan prosedur yang sama dengan perkara perdata biasa lainnya, yang diatur menurut tata cara dalam HIR. Dalam hal ini pengadilan akan melakukan aanmaning atau teguran, dengan memanggil kedua belah pihak secara bersama-sama ke persidangan. Pada prakteknya aanmaning dilakukan 3 tahapan, namun biasanya para pihak tidak sampai melewati 3 tahap aanmaning tersebut, hal ini dikarenakan adanya perdamaian dari para pihak selama proses aanmaning tersebut. Data Pengadilan Negeri Lamongan Lamongan menyebutkan dalam proses aanmaning ada sekitar $25 \%$ para pihak melakukan perdamaian, sehingga pelaksanaan eksekusi putusan arbitrase tidak perlu dilaksanakan.

4. Pelaksanaan eksekusi putusan baik melalui sita, lelang maupun pengosongan Proses aanmaning telah dilaksanakan 3 tahapan, namun pihak yang kalah tidak melaksanakan putusan secara sukarela, maka untuk itu pengadilan akan melakukan pelaksanaan eksekusi putusan arbitrase secara paksa, yang diberikan tugas untuk melakukan eksekusi adalah juru sita Pengadilan Negeri dengan melakukan penyitaan, pelelangan maupun pengosongan. Juru sita melakukan pelelangan, penyitaan dan pengosongan setelah mendapat persetujuan dari Ketua Pengadilan Negeri terhadap pihak yang akan dieksekusi. Objek pelelangan dan penyitaan harus bebas dari sengketa dengan pihak ketiga. Pelelangan dan 
penyitaan ini dimaksudkan sebagai pembayaran uang guna pelunasan utang terhadap kewajiban pihak yang dieksekusi.

Peranan pengadilan dalam eksekusi arbitrase sudah sangat jelas adalah sebagai pelaksana dari eksekusi tersebut. Namun pada prinsipnya pengadilan baru berperan untuk melakukan eksekusi putusan arbitrase apabila adanya permohonan dari pihak yang berkepentingan, karena dalam hal ini pengadilan bersifat pasif. Tanpa adanya permohonan dari pihak yang berkepentingan untuk melakukan eksekusi putusan arbitrase, maka pengadilan tidak dapat menjalankan perannya sebagai pelaksana eksekusi.

\section{Kendala-kendala yang Dihadapi Pengadilan dalam Pelaksanaan Putusan Arbitrase}

Pelaksanaan eksekusi terhadap putusan pengadilan pada intinya harus ada suatu permohonan dari pihak yang berkepentingan agar pengadilan dapat menjalankan perannya selaku eksekutor putusan itu sendiri. Namun pada prakteknya tidak semua putusan arbitrase yang diputus oleh majelis arbitrase dan juga sudah mendapatkan penetapan perintah eksekusi dari Ketua Pengadilan Negeri bisa berjalan pelaksanaan eksekusinya. Adakala suatu putusan yang sudah mendapatkan perintah penetapan perintah eksekusi, dalam proses berikutnya yaitu aanmaning berakhir dengan perdamaian agie pihak-pihak yang bersengketa. Ha1 ini bisa dilihat pada realitanya di Pengadilan Negeri Lamongan, umumnya eksekusi putusan arbitrase yang sampai pada pelaksanaan eksekusinya sendiri hanya $50 \%$ saja. Sedangkan sisanya berakhir dengan berdamainya para pihak saat proses aanmaning dan juga pembatalan putusan arbitrase tersebut.

Putusan arbitrase yang sampai pada tahap pelaksanaan eksekusi, memberikan bantuan juru sita dari Pengadilan Negeri sebagai pihak yang melakukan sita dan juga pelelangan. Namun pelaksanaan eksekusi putusan arbitrase tersebut tidak mudah untuk dilakukan oleh juru sita, pada realitanya masih ada kendala-kendala yang dihadapi dalam pelaksanaannya. Adapun kendala- kendala yang dihadapi pengadilan lebih khususnya juru sita adalah sebagai berikut :

1. Eksekusi barang bergerak

Juru sita dalam melakukan eksekusi terhadap benda-benda bergerak yang dijadikan sebagai objek penyitaan sering mendapatkan kesulitan, karena lokasi dari benda tersebut kadang berpindah-pindah tidak tetap pada satu lokasi Apalagi dalam pelaksaan eksekusi putusan arbitrase asing, karena bendabenda bergerak yang dijadikan objek penyitaan berpindah-pindah dari suatu Negara ke Negara lain. Sebagai contoh benda yang dijadikan objek penyitaan tersebut adalah kapal, pesawat terbang, dan benda-benda lain yang sering berpindah-pindah secara kontinyu dari satu lokasi ke lokasi yang lain.

2. Perlawanan dari pihak yang akan dieksekusi

Juru sita dalam pelaksanaan eksekusi putusan, selain mendapat kendala dari benda bergerak karena sering berpindah-pindah juga mendapat kesulitan apabila pihak yang dieksekusi melakukan perlawanan. Adakalanya pihak yang dieksekusi tidak puas dengan hasil putusan arbitrase yang telah dikeluarkan maupun yang sudah dibuat penetapan perintah eksekusi, sehingga tidak mau melakukan eksekusinya secara sukarela dengan membuat perlawanan atau keonaran. Pihak yang akan dieksekusi secara sengaja tidak mau memberikan objek yang akan dieksekusi secara sukarela, sehingga juru sita dalam hal ini membutuhkan aparat keamanan untuk membantu jalannya proses eksekusi.

3. Aset pembayaran sulit ditemukan

Adakalanya juru sita dalam pelaksanaan eksekusi putusan arbitrase sulit untuk menentukan barang yang akan disita untuk pelunasan pembayaran. Hal ini disebabkan karena pihak yang dieksekusi telah bangkrut atau dinyatakan pailit, sehingga juru sita tidak dapat melakukan penyitaan. Dalam kasus ini apabila objek pelelangan dan penyitaan terdapat sengketa dengan pihak ketiga, juru sita juga akan mendapatkan kesulitan dalam melakukan eksekusinya karena harus menunggu 
proses penyelesaian sengketa antara pihak yang dieksekusi dengan pihak ketiga.

$\begin{array}{rrr}\begin{array}{r}\text { Pengdilan } \\ \text { pelaksanaan }\end{array} & \begin{array}{r}\text { dalam } \\ \text { eksekusi }\end{array} & \begin{array}{r}\text { melankan } \\ \text { putusan }\end{array}\end{array}$

arbitrase, dapat berjalan dengan lancar apabila pihak yang akan dieksekusi melakukannya dengan itikad baik dan sukarela. Tanpa adanya itikad baik dari pihak yang akan dieksekusi, juru sita selaku petugas pelaksananya akan eksekusi secara paksa. Diharapkan dengan selesainya proses pelaksanaan eksekusi arbitrase oleh pengadilan, maka peranan pengadilan dalam arbitrase dapat berjalan sesuai dengan ketentuan yang diatur dalam UU No. 30 Tahun 1999 tentang Arbitrase dan Alternatif Penyelesaian Sengketa tanpa adanya kesalahpahaman kewenangan antara lembaga arbitrase dan lembaga peradilan. Sehingga pada akhirnya penumpukan perkara di lembaga peradilan atau pengadilan dapat berkurang karena semakin banyak para pihak menggunakan proses arbitrase sebagai alternatif penyelesaian sengketa bisnis.

\section{A. Penutup}

\section{Kesimpulan}

Berdasarkan pembalasan di atas, maka penulis dapat mengambil kesimpulan sebagai berikut :

1. Peranan pengadilan dalam pelaksanaan putusan arbitrase yang paling utama adalah sebagai eksekutor atau pelaksana putusan arbitrase tersebut. Untuk dapat dilaksanakan eksekusi, putusan arbitrase wajib didaftarkan di Panitera Pengadilan Negeri, karena apabila tidak didaftarkan putusan arbitrase tidak dapat dilakukan eksekusi. Apabila terjadi keterlambatan pendaftaran, putusan arbitrase tetap masih bisa dilaksanakan, namun hal itu tergantung pertimbangan dari Ketua Pengadilan Negeri apakah akan menerima atau menolak eksekusi putusan arbitrase tersebut. Adapun peranan pengadilan dalam pelaksanaan eksekusi yang lebih umum dapat dirumuskan sebagai berikut :

a. Pemberian exequatur.

b. Penetapan perintah eksekusi.

c. Melakukan teguran atau Aanmaning, d. Pelaksanaan eksekusi putusan baik melalui sita maupun lelang.

2. Dalam menjalankan perannya pengadilan mendapatkan beberapa kendala dalam pelaksana tersebut putusan arbitrase. Adapun kendala-kendala yang dihadapi pengadilan dalam pelaksanaan eksekusi putusan arbitrase adalah sebagai berikut :

a. Eksekusi barang bergerak.

b. Perlawanan dari pihak yang akan dieksekusi.

c. Aset pembayaran sulit ditemukan.

\section{Saran}

Saran yang dapat penulis sampaikan berdasarkan kesimpulan di atas dalam penulisan skripsi ini adalah :

1. Pengadilan dalam menjalankan perannya sebagai pelaksana eksekusi penulisan arbitrase harus mengetahui yuridiksi atau kewenangannya. sehingga tidak terjadi perebutan kewenangan dengan lembaga arbitrase. Dengan adanya keselarasan kewenangan tadi, diharapkan proses arbitrase dapat berjalan dengan lancar sampai pada pelaksanaan eksekusi putusannya.

2. Keberadaan lembaga arbitrase yang merupakan sarana alternatif penyelesaian sengketa seharusnya dapat dimanfaatkan secara efektif dan efisien bagi para pihak yang sedang bersengketa, sehingga penyelesaian sengketa dengan arbitrase dapat berguna dalam membantu lembaga peradilan. Dengan begitu penumpukan yang terjadi di pengadilan dapat berkurang dengan semakin banyaknya pelaku bisnis menempuh alernatif penyelesaian menggunakan arbitrase ini.

\section{DAFTAR PUSTAKA}

\section{LITERATUR:}

Abdurrasyid, Priyatna. 2002. Arbitrase dan Alternatif Penyelesaian Sengketa (APS) Suatu Pengantar. Lamongan : PT Fikahati Anesta.

Ashshofa, Burhan. 2004. Metode Penelitian Hukum. Lamongan : PT Rineka Cipta. 
Fuady, Munir. 2000. Arbitrase Nasional (Alternatif Penyelesaian Sengketa Bisnis). Bandung : PT Citra Aditya Bakti.

Gautama, Sudargo. 1974. Arbitrase Perdagangan Indonesia. Bandung : Alumni. Harahap, Yahya. 2006. Arbitrase. Lamongan : Sinar Grafika.

Margono, Suyud. 2004. ADR (Alternative Dispute Resolutian) dan Arbitrase Proses Pelembagaan dan Aspek Hukum. Lamongan : Ghalia Indonesia.

Miru, Ahmadi. 2007. Hukum Kontrak dan Perancangan Kontrak. Lamongan : PT Raja Grafindo Persada.

Soekanto, Soerjono. 1984. Pengantar Penelitian Hukum. Lamongan : Universitas Indonesia (UI-Press).

Subekti. 1979. Arbitrase Perdagangan. Bandung : PT Citra Aditya Bakti. Sutiyoso, Barabang. 2008. Hukum Arbitrase dan Alternatif
Penyelesaian Sengketa. Yogyakarta : Gama Media.

Widjaja, Guanawan. 2008. SAHDB : Arbitrase Vs Pengadilan Persoalan Kompetensi (Absolut) yang Tidak Pernah Selesai. Lamongan : Kencana.

Widjaja, Gunawan dan Ahmad Yani. 2000. Seri Hukum Bisnis : Hukum Arbitrase. Lamongan : PT Raja Grafindo Persada.

Widjaja, Gunawan dan Michael Adrian. 2008. SAHDB Peran Pengadilan Dalam Penyelesaian Sengketa Oleh Arbitrase. Lamongan : Kencana.

\section{PERUNDANG UNDANGAN:}

UU No. 30 Tahun 1999 tentang Arbitrase dan Alternatif Penyelesaian Sengketa.

UU No. 4 Tahun 2004 tentang Kekuasaan Kehakiman.

Peraturan Prosedur Arbitrase Badan Arbitrase Nasional Indonesia. 